\title{
Stable Isotopes Anomalies of Storm Event in April 2019 in Southwestern Iran: A Method to Characterize the Origin of the Atmospheric Masses
}

Farshad Alijani ( $\sim$ f_alijani@sbu.ac.ir)

Shahid Beheshti University

Soghra Farhadi

Shahid Beheshti University Faculty of Earth Sciences

Hamidreza Nassery

Shahid Beheshti University Faculty of Earth Sciences

\section{Research Article}

Keywords: Stable isotopes, Storm event, Local meteoric water line, South-western Iran, Red Sea atmospheric mass

Posted Date: June 16th, 2021

DOI: https://doi.org/10.21203/rs.3.rs-530955/v1

License: (c) (i) This work is licensed under a Creative Commons Attribution 4.0 International License. Read Full License 
Stable isotopes anomalies of storm event in April 2019 in southwestern Iran: A method to characterize the origin of the atmospheric masses

Soghra Farhadi ${ }^{1}$, Farshad Alijani ${ }^{2 *}$, Hamidreza Nassery ${ }^{3}$

1-PhD Candidate, Department of Minerals and Groundwater Resources, Faculty of Earth Sciences, Shahid Beheshti University

2- Assistant Professor, Department of Minerals and Groundwater Resources, Faculty of Earth Sciences, Shahid Beheshti University, e-mail:__alijani@sbu.ac.ir

3- Professor, Department of Minerals and Groundwater Resources, Faculty of Earth Sciences, Shahid Beheshti University

*Corresponding author

Farshad Alijani

Department of Minerals and Groundwater Resources, Faculty of Earth Sciences, Shahid Beheshti University,

e-mail: $\underline{\text { _alijani@sbu.ac.ir }}$ 


\title{
Stable isotopes anomalies of storm event in April 2019 in southwestern Iran: A method to characterize the origin of the atmospheric masses
}

\begin{abstract}
To determine the source of April 2019 storm event in south-western Iran, stable isotopic technique $\left({ }^{2} \mathrm{H}\right.$ and $\left.{ }^{18} \mathrm{O}\right)$ of precipitation were used. The unique event, with a mean of $230 \mathrm{~mm} / \mathrm{year}$, i.e. $46 \%$ of the annual rainfall over four days, caused large dams on Dez and Karkheh rivers to overflow and a great deal of casualties and financial losses. To determine the characteristics of stable isotopes ${ }^{2} \mathrm{H}$ and ${ }^{18} \mathrm{O}$ of this event, 43 samples of rain water were collected in the area about $41,000(\mathrm{Km})^{2}$ in south-western Iran with altitudes between zero to $2814 \mathrm{~m}$ (m.a.s.l). The local meteoric water line (LMWL) was prepared during the storm event and compared with the global, Mediterranean and other parts of Iran as well as neighbouring countries. According to the LMWL equation $\left(\delta^{2} \mathrm{H}=6.5996 \delta^{18} \mathrm{O}+7.561\right)$ and $d$ excess (with average $7.85 \%$ ), the source of precipitation was the integration of the meteoric masses of Mediterranean and Red Sea. There was a low correlation between the altitude increase and the ${ }^{18} \mathrm{O}$ decrease ( 0.13 per 100 meters), which is a characteristic of this storm event. This isotopic study has proven the impact of Sudanese mass on the occurrence of storm event in south-western Iran for the first time isotopically.
\end{abstract}

Keywords: Stable isotopes, Storm event, Local meteoric water line, South-western Iran, Red Sea atmospheric mass

\section{Introduction}

Precipitation is the last event of vapour transport and phase change (Zhang et al. 2019; Cai etal.2016). The spatial distribution of stable isotopes of precipitation depends on different isotopic effects including continental effect, amount effect, and altitude effect (Dansgaard 1964; Kong et al. 2019).

Craig (1961) described the relationship between these parameters in freshwater for the 
first time, known as the Global Meteoric Water Line (GMWL). It is expressed as equation 1 in equilibrium conditions and temperature of $25^{\circ} \mathrm{C}$. This line is derived from worldwide isotopic precipitation data and averaged over numerous local meteoric water lines (LMWLs) that each has a different slope and intercept (equation 1).

High values of stable $\delta^{2} \mathrm{H}$ and $\delta^{18} \mathrm{O}$ isotopes are in areas close to where the moisture originates and lower values are far from source moisture (Kong etal. 2019). The linear relationship between $\delta^{2} \mathrm{H}$ and $\delta^{18} \mathrm{O}$ is one means to assess the cumulative effects of fractionation caused by evaporation and condensation in samples of precipitation (local meteoric water line, LMWL) and surface/shallow groundwater (local water line, LWL) as compared to the global equilibrium between evaporation and condensation (global meteoric water line, GMWL) defined by the relation 1 (Craig 1961; Ambach 1968):

$$
\delta^{2} \mathrm{H}=8 * \delta^{18} \mathrm{O}+10 \%
$$

LWLs may deviate from the GMWL during any non-equilibrium event, such as evaporation, mixing, or additional input of marine moisture. For example, LWLs with slopes less than or greater than 8 can indicate systems dominated by evaporation and recharge/recycled moisture, respectively (Craig 1961). During the evaporation process, isotopic fractionation causes a difference in the relationship between $\delta^{2} \mathrm{H}$ and $\delta^{18} \mathrm{O}$, so that the $\delta{ }^{2} \mathrm{H}$ values in the vapour decrease faster than those of $\delta^{18} \mathrm{O}$ and therefore the samples are positioned above the GMWL. In contrast, the residual water in the source will be less than the GMWL. Dansgaard (1964) called this difference $d$-excess

$$
\text { d-excess }=\delta^{2} \mathrm{H}-8.0 * \delta^{18} \mathrm{O}
$$

Which has an average of $10 \%$ on a global scale, revealing changes in sources of moisture for precipitation. D-excess in precipitation is due to kinetic subtraction during the 
evaporation process, which is mainly influenced by the relative humidity and temperature of moisture source region (Merlivat et al. 1979; Jouzel 1997) and remains relatively constant during the Rayleigh rainout event (Gat 1996); therefore, it can detect changes in the source of moisture which precipitation originated from it (Florea et al. 2017). Dexcess values deviation from GMWL (higher or lower than $10 \%$ ) shows the effect of air masses source, humidity, temperature, and evaporation (Gat 1996; Lee et al. 2003).

By analyzing $\delta^{18} \mathrm{O}, \delta{ }^{2} \mathrm{H}$ and $d$-excess in regional precipitation we can determine the source of precipitation moisture mass (Sodemann et al. 2008; Jouzel et al. 2013; Wang et al. 2016 a, b, c; Lawrence et al. 1982), monitored patterns of atmospheric masses rotation (Hoffman et al. 2000; Birks et al. 2002), estimate water evaporation (Wang et al. 2016c; Uemura et al. 2012; Jasechko et al. 2014, 2013), restore the past climate conditions (Thompson et al. 2013; Mariani et al. 2014), and identify the surface and groundwater recharge area through the precipitation process and their correlations (Telmer et al. 2000; Gibson et al. 2002; Yonge et al. 1989; Longinelli and Selmo 2003). However, the isotopic composition of precipitation varies temporally and spatially as a result of depletion due to temperature, precipitation, distance from the coastline, altitude effect and climatic conditions (seasonal effect) (Siegenthaler and Oeschger 1980; Windhorst et al. 2013; Gat 1969; Dansgaard 1964). Precipitation isotopic composition changes with altitude, which is called altitude effect and is a major criterion for studying spatial variability, especially in mountainous basins with high variations in elevations. And this has been investigated by many researchers (Cortes et al. 1997; Gonfiantini et al. 2001; Kattan et al. 2006; McGuire et al. 2005; Peng et al. 2010; Siegenthaler and Oeschger 1980; Yurtsever and Gat 1981; Vogel et al. 1975). Most researchers have reported $\delta^{18} \mathrm{O}$ and $\delta^{2} \mathrm{H}$ changes from -0.5 to $-4 \%$ per $100 \mathrm{~m}$ and -0.1 to $-0.6 \%$ per $100 \mathrm{~m}$, respectively. 
Iran is in undesirable situation compared to the average world due to being located in arid and semi-arid region. Although in the southwest of Iran, including Khuzestan province, major rivers such as Karkheh, Dez, Karun, and Zohreh rivers supply a large part of the water requirement, but many parts of this province have not been in the path of these surface waters and supply needs to come from groundwater resource. Therefore, changes in these resources and recent droughts have a direct effect on the lives of people in these areas. The occurrence of drought and its continuance certainly affect the quantity and quality of groundwater resources. Due to the drought occurring in the last 10 years, along with the reduction in surface water, discharge of groundwater resources has been progressive drastically reducing these resources, especially in the northern parts.

The occurrence of 10-year droughts from 2007 to 2016 in the southwest Iran and the beginning of the water scarcity crisis, prediction the source of precipitation in the region is becoming increasingly necessary using precipitation data. This study was conducted to identify and trace massive pulse in Khuzestan province (located in southwest Iran) water resources by determining the isotopic characteristics of unprecedented storm event in southwestern Iran in April 2019 causing a great deal of casualties and financial losses. In southwestern Iran, the air masses originate from the North Atlantic and Mediterranean Sea and the collision of these masses with the Sudanese tropical masses originate from the Red Sea and the Persian Gulf cause heavy rainfall. Most of the area's rainfall occurs in late fall and early spring. However, at first, this storm event has isotopically been associated with the re-formation of the low-pressure Sudanese or Mediterranean atmospheric masses. Given that no such unprecedented rainfall has ever occurred in southwestern Iran, it is important to determine its isotopic characteristics in order to know its origin, storm forecasting based on mass formation and movement, and water resources management. 
In this paper stable isotopic technique $\left({ }^{2} \mathrm{H}\right.$ and $\left.{ }^{18} \mathrm{O}\right)$ was used to determine the variation of isotopic composition of precipitation with altitude (altitude effect), to define the local meteoric water line in southwestern Iran (storm event at April 2019) and to investigate the spatial distribution of stable isotopes (Zagros Mountain Range) and deuterium excess. Since the isotopic patterns depend on the origin of the moisture mass, the local meteoric water line was determined and compared with the global meteoric water line and other parts of Iran and neighboring (western) countries. The relationship between the isotopic values and amount of precipitation (amount effect) has been investigated too. Finally, the origin of the storm event was determined (April 2019). This study on the origin of heavy storms has been performed for the first time in the Middle East.

\section{Materials and methods}

\section{Study area}

The study area with an area of 41,000 $(\mathrm{Km})^{2}$ is located in south-western Iran between latitude $30^{\circ} 30^{\prime}$ to $33^{\circ} 30^{\prime} \mathrm{N}$ and between longitude $48^{\circ}$ to $51^{\circ} \mathrm{E}$. Most of the study area is located in Khuzestan province and parts of itborder with Lorestan and Chaharmahal and Bakhtiari provinces. Figure 1 provides effective air masses upon Iran in the summer and winter seasons. Khuzestan province is divided into two mountainous and plain regions in terms of elevation. The plain covers areas toward the Persian Gulf with very low slope and in some areas, evaporation and lithology have caused salinity of lands and water resources cover approximately $65 \%$ of the province's area. The prevailing west and southwest winds are blowing from Saudi Arabia and Iraq. The mountainous area is located to the north and east of the province (with a northwest-southeast trend) and covers about two fifths of the province's area. The geomorphology of the region consists of consecutive anticlines and synclines of the Zagros Mountains, where anticlines 
correspond to altitudes and synclines to lowlands and plains. The strike of axial surface of these folds is northwest-southeast direction and follows the general stratigraphic structure of Zagros Mountain Range.

The climatic condition in the study area is very complicate and different, so that there are temperate summers and cold winters in mountains and highlands, semi-arid climate in foothills, and arid climate in the lowland areas to the south and southwestern. The winter season in this area is short and temperate while summer is long and warm. Altitude of mean sea level (m.a.s.l) in the study area increases from south to north and maximum elevation in the study area is $4030 \mathrm{~m}$. Surface waters of Khuzestan province originate from neighbouring provinces and pass through lowland and plains to wetlands and Persian Gulf (to south of the study area). The origin of rainfall in the study area is mainly from air masses that enter Iran from the Mediterranean Sea and North Africa (Red Sea) affecting much of the area in Iran. The 40-year and 10-year average precipitation in the study area according to meteorological stations is 577 and $485 \mathrm{~mm}$, respectively. However, during the first four days of April 2019 rainfall with a mean $230 \mathrm{~mm}$ storm event filled the reservoirs of Karkheh $\left(7.3 * 10^{3} \mathrm{MCM}\right)$ and Gotvand Olya $\left(4.5 * 10^{3}\right.$ MCM) dams as a result of a storm that resulted in an overflow of dams and rivers (Dez, Karun, and Karkheh rivers) in the Khuzestan plain causing a great deal of financial and human damage.

[Figure 1 is about here]

\section{Sampling and isotopic analysis}

From 43 locations throughout southwest Iran, 43 rainwater samples were collected during storm event in April 2019 (Figure 2). Samples were collected in polyethylene containers 
with a volume of $50 \mathrm{ml}$ and in order to prevent uneven isotope separation due to evaporation the containers were sealed during sampling time and maintained in the refrigerator at $4{ }^{\circ} \mathrm{C}$. Samples were analyzed in Water Laboratory of Arak University (Iran). The stable isotopic compositions of the precipitation samples are expressed in $\delta$ notation per mille (\%) deviation from the V-SMOW (Vienna Standard Mean Ocean Water) standard (equation 3) and the measurement precision for $\delta^{18} \mathrm{O}$ and $\delta^{2} \mathrm{H}$ is $\pm 0.2 \%$ o and $\pm 0.8 \%$, respectively.

$$
\delta=\left(\frac{\mathrm{R}_{\text {sample }}}{\mathrm{R}_{\text {standard }}}-1\right) \times 1000 \%
$$

where $\delta$ sample is the isotope ratio of the samples to V-SMOW, R sample is the ratio of ${ }^{2} \mathrm{H} / \mathrm{H}$ ${ }^{87}$ or ${ }^{18} \mathrm{O} /{ }^{16} \mathrm{O}$ in the samples $\mathrm{R}$ standard is the ratio of ${ }^{2} \mathrm{H} / \mathrm{H}(0.00015576)$ or ${ }^{18} \mathrm{O} /{ }^{16} \mathrm{O}$ (0.0020052) in V-SMOW (Hao et al. 2019). Differences in climate will result in variations between the isotopic values of $\delta^{2} \mathrm{H}$ and $\delta^{18} \mathrm{O}$ in geographically distinct surface and groundwater sources. Results of analysis of the precipitation samples are summarized in Table 1.

[Figure 2 is about here]

In order to delineate the spatial distribution maps of precipitation and the values of $\delta^{2} \mathrm{H}$ and $\delta^{18} \mathrm{O}$ as well as deuterium excess, the Kriging interpolation method was used. Hatvani et al. (2017) believe that, in this method, the distance and degree of variation between the known points are considered and then the unknown points are estimated using the weighted average of adjacent points. Among the Kriging interpolation methods, the ordinary method was chosen because it provides the best linear distribution for a suitable regional view. 
[Table 1 is about here]

For proper interpolation of all 43 isotopic samples data (for interpolation of $\delta^{2} \mathrm{H}, \delta^{18} \mathrm{O}$ and $d$-excess values) as well as 22 rain gauge stations (for precipitation layer) Surfer 16 and ARC GIS 10.2 software were used. Digital Elevation Model of $15 \times 15 \mathrm{~m}$ was used to extract altitude data.

The $d$-excess (Dansregard 1964) was calculated for each sample as $\mathrm{d}=\delta^{2} \mathrm{H}-8 \delta^{18} \mathrm{O}$ as the secondary isotopic variable. This parameter, reflects the isotopic composition of the initial water vapour, vapour recycling over the continents, and kinetic isotope fractionation by evaporation or condensation during non-equilibrium processes dependent on moisture and sea surface temperature (SST) in the moisture source region (Breitenbach et al. 2010).

Linear regression was used to determine the relationship between elevation, precipitation, and geographical location with the isotopic values of $\delta^{2} \mathrm{H}$ and $\delta^{18} \mathrm{O}$ and $d$-excess in the study area. The altitude, precipitation and geographic location (latitude and longitude) were considered as independent variables and the values of $\delta^{2} \mathrm{H}, \delta^{18} \mathrm{O}$, and $d$-excess were considered as dependent variables. The purpose of regression analysis was to identify the linear model of the relationship between variables.

\section{Results}

\section{Spatial distribution of stable isotopes}

According to the results summarized in Table 1, the value of $\delta^{2} \mathrm{H}$ in the precipitation samples varies from -26.06 to $29.2 \%$. The minimum value of $\delta^{2} \mathrm{H}$ is for the $\mathrm{R} 6$, in which the snow sample was recorded with an altitude of $1617 \mathrm{~m}$ followed by $-25.22 \%$ in the 
$\mathrm{R} 1$ with the highest altitude among the samples, i.e. 2814 meters. The $\delta^{18} \mathrm{O}$ variation is from -4.76 to $4.71 \%$. The minimum value of $\delta^{18} \mathrm{O}$, similar to $\delta^{2} \mathrm{H}$, in the R6 snow sample was recorded with an altitude $1617 \mathrm{~m}$ followed by -4.54 in the highest altitude, i.e. 2814 $\mathrm{m}(\mathrm{R} 1)$. The highest value of $\delta^{18} \mathrm{O}$ was 4.71 in the R16 sample with an altitude of $828 \mathrm{~m}$. On the 3th and 4th of April 2019, in Izeh station (R16) the sum of precipitation was recorded at $97.2 \mathrm{~mm}$, i.e. $20 \%$ of the total annually rainfall, which was one of the highest rainfall in the study area. The distribution of $\delta^{2} \mathrm{H}, \delta^{18} \mathrm{O}$ and $d$-excess values in the study area is shown in Figure 3. It can be said that the isotopes $\delta^{2} \mathrm{H}$ and $\delta^{18} \mathrm{O}$ decrease from south to north and northeast of the study area; in other words, precipitation is depleted from $\delta^{2} \mathrm{H}$ and $\delta^{18} \mathrm{O}$ but there is not a very regular trend. In R41 and R26 samples in the middle part of the study area towards the Masjed Soleiman (MIS) dam R35 (precipitation values 151,88 and $112 \mathrm{~mm}$, respectively) both isotopic values of $\delta^{2} \mathrm{H}$ and $\delta^{18} \mathrm{O}$ have decreased. In fact, $\delta^{2} \mathrm{H}$ and $\delta^{18} \mathrm{O}$ in these three samples have decreased with an increase in the altitude. To the northeast of the study area, an increasing trend (enrichment) of isotopic values is observed and after that the isotopes decrease again.

[Figure 3 is about here]

\section{Deuterium excess (d) and determination of moisture source}

Deuterium excess $(d)$ varied from -9.3 to $15.6 \%$ in 43 rainwater samples, of which 15 samples were more than $10 \%$ and 27 samples less than $10 \%$. The average was 7.85 , which is lower than the global $d$-excess (10). This indicates that most of the precipitation originate from areas with high evaporation and that the rain is due to the mixture of water vapour from the Mediterranean and the Red Sea atmospheric masses. In the near vicinity of the dam reservoirs, the $d$-excess is near $10 \%$ and more. 
In the study area, from south and southwest to higher altitudes (north and northeast) the $d$-excess values increase (Figure $3 \mathrm{c}$ ). Considering that $d$-excess decreases with the enrichment of the isotopic composition and increases with the depletion of the isotopic composition, it can be concluded that the isotopic composition is depleted towards the altitudes of the study area (north and northeast).

\section{Isotope effects due to precipitation amount (amount effect)}

Figure 4 depicts of precipitation map of storm event in April 2019. The amount of precipitation has increased from south to north and northeast increasing to more than 520 $\mathrm{mm}$ in the northern elevations of the study area. With an increase in rainfall, $\delta^{18} \mathrm{O}$ and $\delta^{2} \mathrm{H}$ values have decreased. The decrease in $\delta^{2} \mathrm{H}$ is more pronounced than that in $\delta^{18} \mathrm{O}$, so that the dispersion of $\delta^{2} \mathrm{H}$ values is high. Therefore, with an increase in rainfall, the $\delta^{18} \mathrm{O}$ and $\delta^{2} \mathrm{H}$ isotopes are depleted. The correlation between $\delta^{18} \mathrm{O}$ and precipitation amount $\left(\mathrm{R}^{2}=0.0957\right)$ is stronger than the relationship between $\delta^{2} \mathrm{H}$ and precipitation $\left(\mathrm{R}^{2}=\right.$ 0.0708), which is probably due to the storm event and mixing of Sudanese and Mediterranean atmospheric masses at higher altitudes; therefore, the effect of precipitation amount (amount effect) is disrupted.

[Figure 4 is about here]

\section{Relationship between the $\delta^{18} \mathrm{O}$ and $\delta^{2} \mathrm{H}$ values and altitude (altitude effect)}

The altitude in the southern and margins of the Persian Gulf is low and close to zero and increases to the north and northeast. The maximum elevation in the northeast of study 
area is 4030 meters. Figure 5 illustrates the relationship between the values of $\delta^{2} \mathrm{H}, \delta^{18} \mathrm{O}$, and $d$ - excess with altitude.

[Figure 5 is about here]

The equation for the increase in $\delta^{18} \mathrm{O}$ with altitude in this study is as follows:

$$
\delta^{18} \mathrm{O}=-0.0013 * \text { Alt. }+0.866
$$

Alt. is the elevation (m.a.s.l). This result confirms the altitude effect. In other words, the value of $\delta^{18} \mathrm{O}$ decreases with an increase in altitude (Dansregard 1964; Smith et al. 1979). The equation for decreasing $\delta^{2} \mathrm{H}$ with altitude is as:

$$
\delta^{2} \mathrm{H}=-0.0091 * \text { Alt. }+13.387
$$

Alt. is the elevation (m.a.s.1). In this study, according to Figure 5 the reduction rates of isotopic values $\left(\delta^{2} \mathrm{H}\right.$ and $\left.\delta^{18} \mathrm{O}\right)$ with an increase in altitude were -0.91 and $-0.13 \%$ per $100 \mathrm{~m}$ height, respectively. Therefore, the decreasing rate of $\delta^{18} \mathrm{O}$ is almost consistent with the global GNIP value reported by Rozanski et al. (1993) (-0.15 \%o to $-0.6 \%$ per $100 \mathrm{~m}$ ), but the magnitude of the $\delta^{2} \mathrm{H}$ reduction rate is lower than the rate reported by Yurtsever and Gat (1984) (-1.5\% to $-4.0 \%$ per 100 m). D-excess increases with altitude, and its equation is as follows:

$$
d \text {-excess }=0.0019 * \text { Alt. }+6.3747
$$

The altitude in the southern study and margins of the Persian Gulf are low and close to zero increasing towards the north and northeast. The maximum elevation in the northeast 
of study area is 4032 meters above sea level (Figure 6). Three cross-sections (AA', BB' and $\mathrm{CC}^{\prime}$ ) are presented on the DEM.

[Figure 6 is about here]

A is the elevation (m.a.s.l). Figures 7 to 9 illustrate several cross-sections in the digital elevation model and the changing state of precipitation and isotopic values. In AA' crosssection, the overall trend of altitude change is increasing (6 a) and precipitation has increased ( $6 \mathrm{~b})$. At the same section, the $\delta^{18} \mathrm{O}$ and $\delta^{2} \mathrm{H}(6 \mathrm{c})$ isotopes value at the beginning of the cross section has changed with precipitation, then increasing and decreasing again with steeper slopes. D-excess has also been studied showinng an irregular trend (6 d). In BB ' cross-section, with an increase in altitude ( $7 \mathrm{a})$, precipitation has increased $(7 \mathrm{~b})$, the $\delta^{18} \mathrm{O}$ and $\delta^{2} \mathrm{H}(7 \mathrm{c})$ initially have decreased, then increasing and decreasing again. Dexcess has shown an increasing trend in this section $(7 \mathrm{~d})$. In $\mathrm{CC}^{\prime}$ cross-section, with an increase in altitude ( 8 a) and precipitation $(8 \mathrm{~b})$ the isotopes of $\delta^{18} \mathrm{O}$ and $\delta^{2} \mathrm{H}$ have a decreasing trend $(8 \mathrm{c})$. D-excess of this section has no clear trend as presented in Fig. 8 d.

[Figure 7 is about here]

[Figure 8 is about here]

[Figure 9 is about here] 


\section{Discussion}

\section{GMWL, LMWL and neighboring countries of Iran}

Precipitation isotopic data (Table 1) are used to provide the local meteoric water line (LMWL) of the study area. LMWL is plotted from the relationship between $\delta^{18} \mathrm{O}$ and $\delta^{2} \mathrm{H}$ as seen in Figure 10. The equation obtained for the LMWL is as follows:

$$
\delta^{2} \mathrm{H}=6.5996 * \delta{ }^{18} \mathrm{O}+7.561 \%
$$

[Figure 10 is about here]

It is clear that the slope of southwestern Iran LMWL is slightly slower than that of the GMWL, as the movement of the air masses toward the precipitation site produces rain that evaporates in the lower parts of the cloud. Figure 11 shows the graph of the LMWL as compared to the GMWL, Eastern (EMMWL), and Central Mediterranean (CMMWL) and neighboring countries of Iran (southwest). The Eastern Mediterranean meteoric water line (EMMWL) is as follows (Gat and Carmi 1970):

$$
\text { EMMWL; } \delta^{2} \mathrm{H}=8 * \delta{ }^{18} \mathrm{O}+22 \%
$$

According to the study of Liotta et al. (2008) the equation of the Central Mediterranean meteoric water line (CMMWL) equation is as follows:

$$
\text { CMMWL; } \quad \delta^{2} \mathrm{H}=6.5 * \delta{ }^{18} \mathrm{O}+5.28 \%
$$

According to the study of Ali et al. (Ali et al. 2015) Iraq meteoric water line is as follows: 


$$
\delta^{2} \mathrm{H}=7.573 \delta^{18} \mathrm{O}+13.82 \%
$$

The source of Iraq rainfall is a mixture of Mediterranean, Persian Gulf, and Atlantic waters (Ali et al. 2015). According to the results of Kattan (2006) study, the average Syrian meteoric water line based on the survey of 16 stations is as follows:

$$
\delta^{2} \mathrm{H}=6.17 * \delta^{18} \mathrm{O}+5.7 \%
$$

and the source of precipitation is the Mediterranean Sea. Turkey's meteoric water line based on the results of Dirican et al. (2005) studies is as follows:

$$
\delta^{2} \mathrm{H}=7.74 * \delta^{18} \mathrm{O}+13.1
$$

[Figure 11 is about here]

Considering the situation of sampling points in the study area, it is observed that some points are located between the global and Mediterranean meteoric line and with respect to the slope of the line less than the GMWL and the mean of $d$-excess (less than $10 \%$ ) it can be concluded that the source of the storm event is a mixture of the Mediterranean Sea and the Sudanese atmospheric masses which cross the Arabian Sea and the Persian Gulf.

\section{Meteoric water line of other parts of Iran}

According to studies in some areas of Iran, local meteoric water line of north (Shahrood and Gorgan), south (Shiraz), west (Kandand-Zahab-Karkheh basin), east (Rafsanjan), and central Iran (Tehran and Isfahan) have been provided. Table 2 and Figure 12 illustrate the equation and the LMWL for these areas. 
[Table 2 is about here]

The average rainfall in the surveyed areas $(299 \mathrm{~mm})$ is similar to the average annual precipitation in the whole of Iran $(250 \mathrm{~mm})$. Given that the amount of precipitation is one of the important factors controlling precipitation isotopic properties, and because the average rainfall in the studied areas except Gorgan is close to the average rainfall of Iran, it can be concluded that the average line of these regions according to equation 13 represents the Iranian meteoric water line in dry regions. The slope of LMWL is between 5 and 8 (Shamsi and Kazemi 2014). In fact, the slope of Iranian LMWL is lower than that of the GMWL, which describes the prevailing dry and semi-arid climate in Iran. In such a climate condition, secondary evaporation of raindrops enriches heavy isotopes:

$$
\delta^{2} \mathrm{H}=6.895 * \delta^{18} \mathrm{O}+6.57 \% \text { o } \quad \mathrm{R}^{2}=0.93
$$

[Figure 12 is about here]

Isotopically heavier water falls first during a precipitation event; thus, $\delta^{18} \mathrm{O}$ and $\delta^{2} \mathrm{H}$ values decrease during progressive precipitation from adiabatic cooling along an altitude gradient — an altitude lapse rate (Dansregard 1964; Clark and Fritz 1997). According to Clark and Fritz (1997) altitude rate is $(-0.5 \%)$ to $(-0.15 \%)$ per $100 \mathrm{~m}$ elevation. The relationship between isotopic values and altitude is shown in Figure 5. With increasing elevation, the isotopic values have decreased. Reduced rates were -0.13 and -0.91 per 100 $\mathrm{m}$ for $\delta^{18} \mathrm{O}$ and $\delta^{2} \mathrm{H}$, respectively, based on the equations 4 and 5.

The term amount effect was presented by Dansgaard (1964), which showed a negative 
relationship between $\delta^{18} \mathrm{O}$ and precipitation. This effect, which primarily depends on the meteorological conditions at the time of rain fall (temperature and relative humidity), is usually due to several factors: (i) a decrease in the isotopic composition of the condensate in a cloud as cooling and raining proceed; (ii) quick equilibrium of small raindrops with ambient water vapour and temperature conditions compared to larger raindrops; and (iii) fast evaporation of small raindrops during their falling on the land surface compared to larger raindrops (Rozanski et al. 1993; Ali et al. 2015).

In the study area, with increasing rainfall, the decreasing of $\delta^{2} \mathrm{H}$ is steeper than that of $\delta^{18} \mathrm{O}$. So the correlation between depletion of $\delta^{18} \mathrm{O}$ and precipitation $(\mathrm{R}=0.0913)$ is stronger than the relationship between $\delta^{2} \mathrm{H}$ depletion $(\mathrm{R}=0.0692)$, which is probably due to the storm event and the mixing of the Sudanese (Red Sea) and the Mediterranean Sea atmospheric masses at high altitudes and the disruption of the amount effect.

The typically low $d$-excess is due to re-evaporation in the cloud, which also results in the enrichment of heavy isotopes in precipitation. Lower $d$-excess values are always associated with low precipitation and high evaporation (Wang et al. 2019). Due to the effect of recirculation of moisture from local surface water such as dams and soil water, $d$-excess values increase (Froehlich et al. 2008; Warrier et al. 2010).

D-excess is an index of evaporation effect on the physico-chemical properties of water, so that if water evaporates, the $d$-excess is reduced (Tsujimura et al. 2007). The range of variation of d-excess of precipitation is -9.3 to 15.6 with an average of 7.85 , which is lower than the global amount. This indicates that much of the region's rainfall (storm event) originates from areas with high evaporation. 


\section{Conclusion}

In this study, the values of $\delta^{18} \mathrm{O}, \delta^{2} \mathrm{H}, d$ - excess $(d)$ and LMWL for storm event in April 2019 in southwestern Iran were investigated. The relationship between isotopic variations and precipitation amount, geographical location, and altitude in the storm event were evaluated. The LMWL was compared with that in other parts of Iran, as well as the eastern and central Mediterranean, GMWL, neighbouring countries including Iraq, Turkey and Syria. The LMWL equation of the study area is $\delta^{2} \mathrm{H}=6.5996 * \delta^{18} \mathrm{O}+7.561$ and $d$-excess indicates that the source of precipitation is due to the integration of the low-pressure Mediterranean and the low-pressure Red Sea and Oman Sea atmospheric masses. There is a good correlation between an increase in altitude and the decrease in $\delta^{18} \mathrm{O}$ and $\delta^{2} \mathrm{H}$ such that the rate of the decrease in $\delta^{18} \mathrm{O}$ with altitude is $-0.13 \%$ per $100 \mathrm{~m}$ and the rate of $\delta^{2} \mathrm{H}$ decrease with elevation is $0.91 \%$ per $100 \mathrm{~m}$ indicates the altitude effect. The isotopic composition of precipitation has been more depleted with increasing latitude and longitude indicating a continental effect. The combination of spatial and seasonal variations of isotopic composition and deuterium excess values can be an effective tool for tracing moisture in the hydrological cycle.

Investigation of isotopic characteristics and $d$-excess of storm event in April 2019 in southwestern Iran has shown the impact of the Sudanese masses (low-pressure) on heavy rainfall in southwestern Iran. Since the Sudanese mass originates in the areas around the Red Sea, their low pressure lines cover the south of the Red Sea, Sudan and Ethiopia then acrosses through southwestern Iran causing heavy rainfall,. This isotopic study has proven the impact of Sudanese mass on the occurrence of storm event in southwestern Iran and part of Middle East including Saudi Arabia, Iraq and neighboring countries in south of Iran, for the first time, isotopically. 


\section{Disclosure statement}

No potential conflict of interest was reported by the authors.

\section{Acknowledgments}

Our special thanks to the Khuzestan Water and Power Authority Co., Khuzestan Province, Iran, for their help in providing meteorological data, sampling of precipitation during the storm event in April 2019, and partial financial support for stable isotopes analyses. 


\section{References}

Ali KK, Al-Kubaisi QY, Al-Paruany KB (2015) Isotopic study of water resources in a semi-arid region, western Iraq. Environ Earth Sci 74: 1671-1686. doi:10.1007/s12665-015-4172-6

Ambach W, Dansgaard W, Eisner H et al (1968) The altitude effect on the isotopic composition of precipitation and glacier ice in the Alps. Tellus 20: 595-600. doi: 10.3402/tellusa.v20i4.10040.

Birks SJ, Gibson JJ, Gourcy L et al (2002) Maps and animations offer new opportunities for studying the global water cycle. EOS: Trans Am Geophys Union 83(37): 406. doi:10.1029/2002eo000298.

Breitenbach SFM, Adkins JF, Meyer H et al. Strong influence of water vapor source dynamics on stable isotopes in precipitation observed in Southern Meghalaya, NE India. Earth Planet. Sci. Lett. 2010; 292(1-2): 212-220. doi:10.1016/j.eps1.2010.01.038.

Cai Z, Tian L. Atmospheric controls on seasonal and interannual variations in the precipitation isotope in the east Asian monsoon region. J. Clim. 2016; 29(4): 1339-1352. doi:10.1175/jcli-d-15-0363.1.

Clark ID, Fritz P (1997) Environmental Isotopes in Hydrogeology. CRC Press/Lewis Publishers, Boca Raton, FL.

Cortes A, Durazo J, Farvolden RN (1997) Studies of isotopic hydrology of the basin of Mexico and vicinity: annotated bibliography and interpretation, J Hydrol 198(14): 346-376, doi:10.1016/S0022-1694(96)03273-8.

Craig H (1961) Isotopic variations in meteoric waters. Science 133: 1702-1703. doi:10.1126/science.133.3465.1702

Dansgaard W (1964) Stable isotopes in precipitation. Tellus 16: 436-468.

Dirican A, Ünal S, Demircan M (2005) The temporal and seasonal variation of H-2 and O-18 in atmospheric water vapor and precipitation from Ankara, Turkey in relation to air mass trajectories at Mediterranean Basin. Final report of a coordinated research project 2000-2004, IAEA-TECDOC-1453.

Farpoor M, Khademi H, Eghbal M et al (2004) Mode of gypsum deposition in south eastern Iranian soils as revealed by isotopic composition of crystallization water. Geoderma 12: 233-242. doi:10.1016/j.geoderma.2003.11.013. 
Florea L, Bird B, Lau J K et al (2017) Stable isotopes of river water and groundwater along altitudinal gradients in the high Himalayas and the eastern Nyainqentanghla Mountains. J Hydrology: Regional Studies 14: 37-48. doi:10.1016/j.ejrh.2017.10.003

Froehlich K, Kralik M, Papesch W et al (2008) Deuterium excess in precipitation of Alpine regions - moisture recycling. Isotopes Environ Health Stud 44: 61-70. doi:10.1080/ 10256010801887208

Gat JR (1996) Oxygen and hydrogen isotopes in the hydrologic cycle. J. Annual Review of Earth and Planetary Science 24(1): 225-262. doi:10.1146/annurev.earth.24.1.225.

Gat JR, Carmi I (1970) Evolution in the isotopic composition of atmospheric waters in the Mediterranean Sea area. J Geophys Res 75(15): 3039-3048. doi:10.1029/jc075i015p03039.

Gibson JJ, Edwards TWD (2002) Regional surface water balance and evapotranspiration partitioning from a stable isotope survey of lakes in northern Canada. Glob. Biogeochem. Cycle 16(2): 10-1-10-14. doi: 10.1029/2001GB001839.

Gonfiantini R, Roche, MA, Olivry JC et al (2001) The altitude effect on the isotopic composition of tropical rains. Chem Geol 181(1-4): 147-167. doi:10.1016/s00092541(01)00279-0.

Hao Sh, Li F, Li Y et al (2019) Stable isotope evidence for identifying the recharge mechanisms of precipitation, surface water, and groundwater in the Ebinur Lake basin. Science of the Total Environment 657: 1041-1050. doi:10.1016/j.scitotenv.2018.12.102.

Hatvani IG, Leuenberger M, Kohan B et al (2017) Geostatistical analysis and isoscape of ice core derived water stable isotope records in an Antarctic macro region. J Polar Science 13: 23-32. doi:10.1016/j.polar.2017.04.001.

Hoffman G, Jouzel J, Masson V (2000) Stable water isotopes in atmospheric general circulation models. Hydrol Process 14: 1385-1406. https://doi.org/10.1002/10991085(20000615)14:8<1385:AID-HYP989>3.0.CO;2-1.

IAEA/WMO (2013) Global Network of Isotopes in Precipitation. Available via http://isohis.iaea.org. 
Jasechko S, Gibson JJ, Edwards TWD (2014) Stable isotope mass balance of the Laurentian Great Lakes. $J$ Great Lakes Res 40(2): 336-346. doi:10.1016/j.jglr.2014.02.020.

Jasechko S, Sharp ZD, Gibson JJ et al (2013) Terrestrial water fluxes dominated by transpiration. Nature 496(7445): 347-350. doi:10.1038/nature11983

Jouzel J, Alley RB, Cuffey KM et al (1997) Validity of the temperature reconstruction from water isotopes in ice cores. J Geophys Res 102(C12): 26471-26487. doi:10.1029/97jc01283.

Jouzel J, Delaygue G, Landais A (2013) Water isotopes as tools to document oceanic sources of precipitation. J Water Resources Res 49(11): 7469-7486. doi:10.1002/2013wr013508.

Karimi H (2013) Investigating composition of ${ }^{18} \mathrm{O}$ and ${ }^{2} \mathrm{H}$ stable isotopes in precipitations of West Zagros. In: Proceedings of the 1st National Conference on Application of Stable Isotopes, Mashhad, Iran: 110-115.

Kattan Z (2006) Characterization of surface water and groundwater in the Damascus Ghotta basin: hydrochemical and environmental isotopes. J Environ Geol 51(2): 173-201. doi:10.1007/s00254-006-0316-z.

Kazemi GA (2013) Isotope composition $\left({ }^{18} \mathrm{O}\right.$ and $\left.{ }^{2} \mathrm{H}\right)$ in precipitations of Shahrood area. In: Proceedings of the 1st National Conference on Application of Stable Isotopes, Mashhad, Iran: 54-60.

Khademi H, Mermut AR, Krouse HR (1997) Isotopic composition of gypsum hydration water in selected landforms from central Iran. J Chem Geol 138(3-4): 245-255. doi:10.1016/s0009-2541(97)00017-x.

Khalili K, Tahoudi MN, Mirabbasi R et al (2016) Investigation of spatial and temporal variability of precipitation in Iran over the last half century. J Stoch Environ Res Risk Assess 30(4): 1205-1221. doi:10.1007/s00477-015-1095-4.

Kong Y, Wang K, Li J et al (2019) Stable isotopes of precipitation in China: A consideration of moisture sources. J Water 11(6): 1239. doi:10.3390/w11061239.

Lawrence JR, Gedzelman SD, White JWC (1982) Storm trajectories in eastern US: D/H isotopic composition of precipitation. $J$ Nature 296(5858): 638-640. doi:10.1038/296638a0. 
Lee K, Grundstein A, Wenner DB et al (2003) Climatic controls on the stable isotopic composition of precipitation in Northeast Asia. Clim Res 23: 137-148. doi:10.3354/cr023137 (https://doi.org/10.3354/cr023137)

Liotta M, Favara R, Valenza M (2008) Isotopic composition of the precipitations in the central Mediterranean: Origin marks and orographic precipitation effects. $J$ Geophys Res: Atmos 111(D19). doi:10.1029/2005jd006818.

Longinelli A, Selmo E (2003) Isotopic composition of precipitation in Italy: A first overall map. J Hydrol 270(1-2): 75-88. doi:10.1016/s0022-1694(02)00281-0.

Mariani I, Eichler A, Jenk TM et al (2014) Temperature and precipitation signal in two Alpine ice cores over the period 1961-2001. Clim Past 10: 1093-1108. doi:10.5194/cp-10-1093-2014.

McGuire KJ, McDonnell JJ, Weiler M et al (2005) The role of topography on catchmentscale water residence time. Water Resour Res; 41, W05002, doi:10.1029/2004WR003657.

Merlivat L, Jouzel J (1979) Global climatic interpretation of the deuterium-oxygen 18 relationship for precipitation. J Geophys Res: Ocean 84(C8): 5029. doi:10.1029/jc084ic08p05029.

Mohammadzadeh H, Amiri V (2019) Investigation of (Alluvial and Karstic) Groundwater Residence Time in Pol-e-Zahab Study Area Using Spatiotemporal Variations of Isotopic Composition $(\delta 2 \mathrm{H}, \delta 18 \mathrm{O}) . J$ Iran-Water Resources Res 15(1): 327-340

Mohammadzadeh H, Ebrahimpoor S (2012) Application of stable isotopes and hydrochemistry to investigate sources and quality exchange Zarivar catchment area. J Water Soil 26: 1018-1031.

Osati K, Koeniger P, Salajegheh A (2013) Spatiotemporal patterns of stable isotopes and hydrochemistry in springs and river flow of the upper Karkheh River Basin, Iran. Isot Environ Health Stud 50: 169-183. doi:10.1080/10256016.2014.857317.

Peng TR, Wang CH, Huang CC et al (2010) Stable isotopic characteristic of Taiwan's precipitation: A case study of western Pacific monsoon region. Earth Planet Sci Lett 289(3-4): 357-366, doi:10.1016/j.epsl.2009.11.024.

Rozanski K, Araguas-Araguas LJ, Gonfiantini R (1993) Isotopic patterns in modern global precipitation. In: Climate Change in Continental Isotopic Records (eds. 
Swart PK, Lohmann KC, Mckenzie, J and Savin S). Geophysical Monograph, Washington, DC: 1-36.

Scholl MA, Shanley JB, Zegarra JP et al (2009) The stable isotope amount effect: New insights from NEXRAD echo tops, Luquillo Mountains, Puerto Rico. J Water Resources Res 45(12). doi:10.1029/2008wr007515.

Shamsi A, Kazemi GA (2014) A review of research dealing with isotope hydrology in Iran and the first Iranian meteoric water line. J Geope 4(1): 73-86.

Siegenthaler U, Oeschger H (1980) Correlation of ${ }^{18} \mathrm{O}$ in precipitation with temperature and altitude. J Nature 285(5763): 314-317. doi:10.1038/285314a0.

Smith GI, Friedman I, Klieforth H et al (1979) Areal distribution of deuterium in eastern California precipitation, 1968-1969.J Appl Meteorol 18(2): 172-188. doi:10.1175/1520-0450(1979)0182.0.co;2

Sodemann H, Masson-Delmotte V, Schwierz C et al (2008) Interannual variability of Greenland winter precipitation sources: 2. Effects of North Atlantic Oscillation variability on stable isotopes in precipitation.J Geophys Res 113: D12111, doi:10.1029/2007JD009416.

Telmer K, Veizer J (2000) Isotopic constraints on the transpiration, evaporation, energy and GPP budgets of a large boreal watershed: Ottawa River basin, Canada. Glob Biogeochem Cycle 14(1): 149-165. doi:10.1029/1999gb900078.

Thompson LG, Mosley-Thompson E, Davis ME et al (2013) Annually resolved ice core records of tropical climate variability over the past $\sim 1800$ years, Science 340: 945-950. doi:10.1126/science. 1234210

Tsujimura M, Abe Y, Tanaka T (2007) Stable isotopic and geochemical characteristics of groundwater in Kherlen River basin, a semiarid region in eastern Mongolia. $J$ Hydrol 333(1): 47-57. doi:10.1016/j.jhydrol.2006.07.026.

Uemura R, Yonezawa N, Yoshimura et al (2012) Factors controlling isotopic composition of precipitation on Okinawa Island, Japan: implications for paleoclimate reconstruction in the East Asian Monsoon region. J Hydrol 475:314322. doi:10.1016/j.jhydrol.2012.10.014.

Vogel JC, Lerman JC, Mook W (1975) Natural isotopes in surface and groundwater from Argentina. J Hydro Sci Bull XX(2): 203-221.

Wang S, Zhang M, Hughes CE et al (2016a) Factors controlling stable isotope composition of precipitation in arid conditions: an observation network in the 
Tianshan Mountains, central Asia. Tellus B Chem Phys Meteorol 68(1):289-299. doi: 10.3402/tellusb.v68.26206

Wang L, Dong Y, Han D et al (2019) Stable isotopic compositions in precipitation over wet Island in Central Asia. $J$ Hydrol 573: 581-591. https://doi.org/10.1016/j.jhydrol.2019.04.005.

Wang S, Zhang M, Che Y et al (2016b) Contribution of recycled moisture to precipitation in oases of arid central Asia: A stable isotope approach. Water Resour Res 52(4): 3246-3257. doi:10.1002/2015WR018135

Wang S, Zhang M, Che Y et al (2016c) Influence of below-cloud evaporation on deuterium excess in precipitation of arid central Asia and its meteorological controls. J Hydrometeorol 17(7): 1973-1984. doi: 10.1175/JHM-D-15-0203.1

Warrier CU , Babu MP, Manjula P et al (2010) Isotopic characterization of dual monsoon precipitation-evidence from Kerala, India. Curr Sci 98(11): 14871495. https://www.jstor.org/stable/24108220.

Windhorst D, Waltz T, Timbe et al (2013) Impact of elevation and weather patterns on the isotopic composition of precipitation in a tropical montane rainforest. Hydrol Earth Syst Sci 17:409-419. doi:10.5194/hess-17-409-2013

Yonge CJ, Goldenberg L, Krouse HR (1989) An isotope study of water bodies along a traverse of southwestern Canada. $J$ Hydrol 106 (3-4): 245-255. https://doi.org/10.1016/0022-1694(89)90075-9.

Yurtsever Y, Gat J R (1981) Atmospheric waters (eds) Gat JR and Gonfiantini R, Stable isotope hydrology: deuterium and oxygen-18 in the water cycle, IAEA, Technical reports series 210:103-142.

Zhang T, Zhang Y, Guoa Y et al (2019) Controls of stable isotopes in precipitation on the central Tibetan Plateau: A seasonal perspective. Quat Int 513: 66-79. https://doi.org/10.1016/j.quaint. 


\section{Table Captions}

Table 1- Isotopic composition $\left(\delta^{18} \mathrm{O}, \delta^{2} \mathrm{H}, d\right.$ - excess $(d)$ and Altitude) of rain water sampling points within the study area (April 2019)

Table 2- Equation of local meteoric water line (LMWL) of some parts of Iran in the present study 


\section{Figure Captions}

Figure 1. Effective air masses upon Iran in the summer and winter seasons [62]

Figure 2. Location of sampling points and study area in southwestern Iran

Figure 3. Distribution of (a) $\delta 18 \mathrm{O}$, (b) $\delta 2 \mathrm{H}$ (c) d-excess in rainwater samples throughout the study area during the storm event in April 2019

Figure 4. Map of iso-precipitation of the storm event (April 2019)

Figure 5. Correlation between altitude and isotopic values

Figure 6. Digital Elevation Model (DEM) of study area and cross sections

Figure 7. AA' cross-section in DEM of study area, a) altitude variation, b) precipitation, c) $\delta 18 \mathrm{O}$ and $\delta 2 \mathrm{H}, \mathrm{d}) \mathrm{d}$-excess

Figure 8. BB' $^{\prime}$ cross-section in DEM of study area, a) altitude variation, b) precipitation, c) $\delta 18 \mathrm{O}$ and $\delta 2 \mathrm{H}, \mathrm{d}) \mathrm{d}$-excess

Figure 9. CC' cross-section in DEM of study area, a) altitude variation, b) precipitation, c) $\delta 18 \mathrm{O}$ and $\delta 2 \mathrm{H}, \mathrm{d}) \mathrm{d}$-excess

Figure 10. Plotted rain water samples on $\delta 2 \mathrm{H}$ vs. $\delta 180$ diagram LMWL and compared with GMWL

Figure 11. LMWL (April 2019), compared with GMWL, EMMWL, CMMWL and Adjacent Countries (Turkey, Syria and Iraq)

Figure 12. Local meteoric water line (LMWL) of some parts of Iran in present study 


\section{Figures}

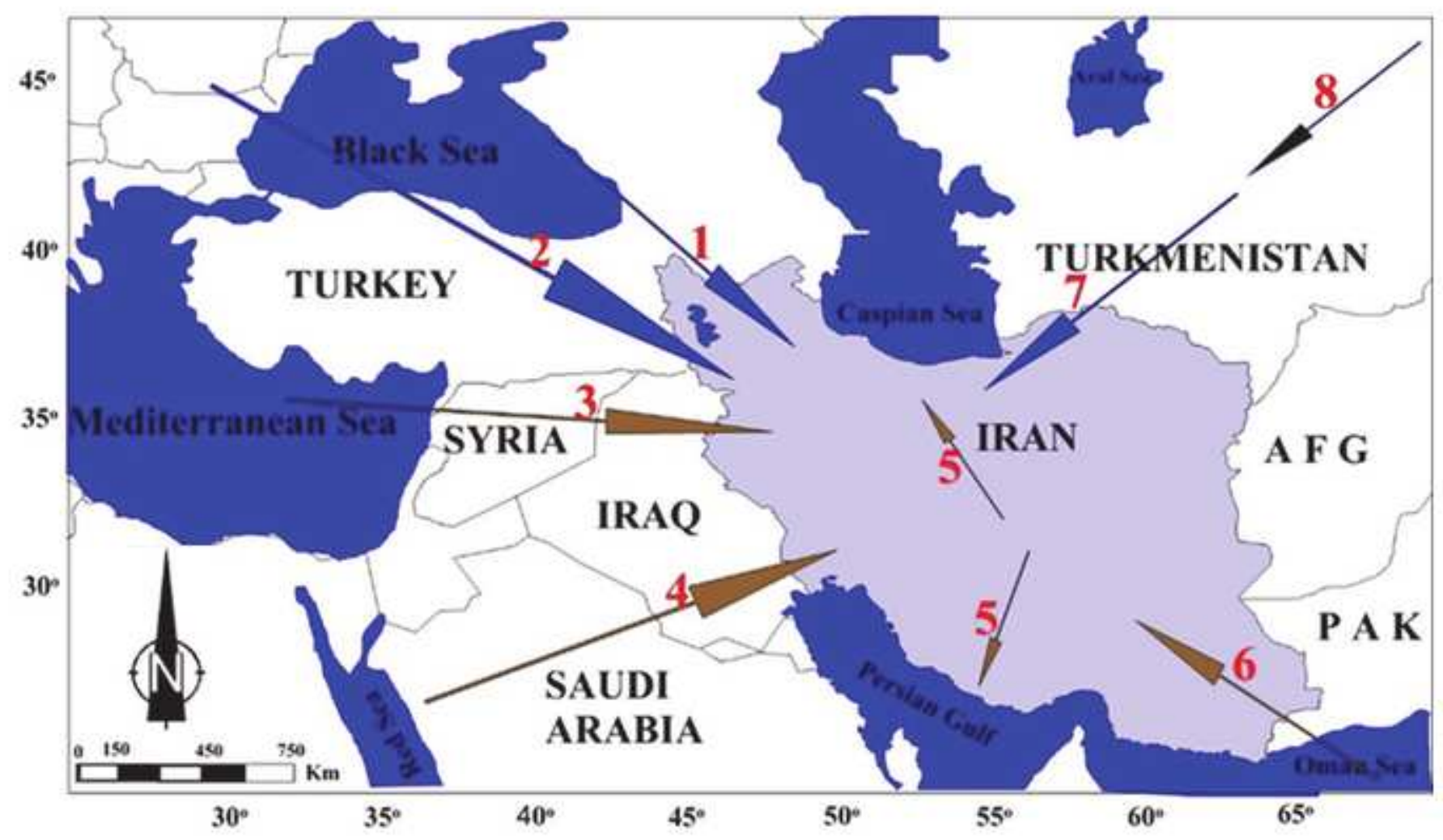

1 Continental polar air masses originating from Europe

2 Maritime polar air masses from the North Atlantic

3 Maritime tropical air masses originating from the Azores

4 Continental tropical air masses Saudi Arabia and North Africa

5 Continental tropical air masses(the central plateau of Iran)

6 Equatorial air masses from the Indian Ocean

7 Continental polar air masses originating from Siberia

8 Arctic air masses

\section{Figure 1}

Effective air masses upon Iran in the summer and winter seasons [62] Note: The designations employed and the presentation of the material on this map do not imply the expression of any opinion whatsoever on the part of Research Square concerning the legal status of any country, territory, city or area or of its authorities, or concerning the delimitation of its frontiers or boundaries. This map has been provided by the authors. 


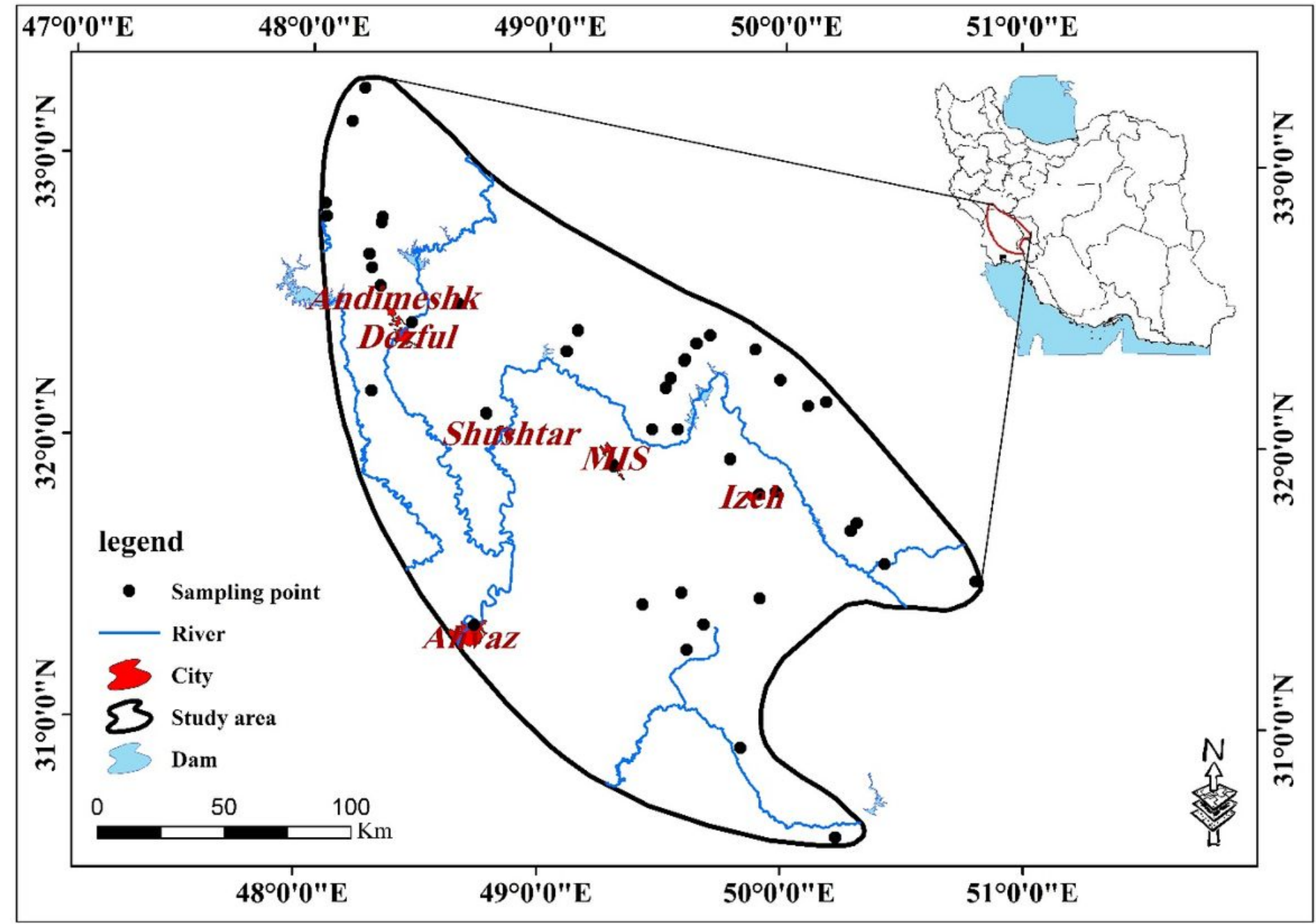

Figure 2

Location of sampling points and study area in southwestern Iran. Note: The designations employed and the presentation of the material on this map do not imply the expression of any opinion whatsoever on the part of Research Square concerning the legal status of any country, territory, city or area or of its authorities, or concerning the delimitation of its frontiers or boundaries. This map has been provided by the authors. 


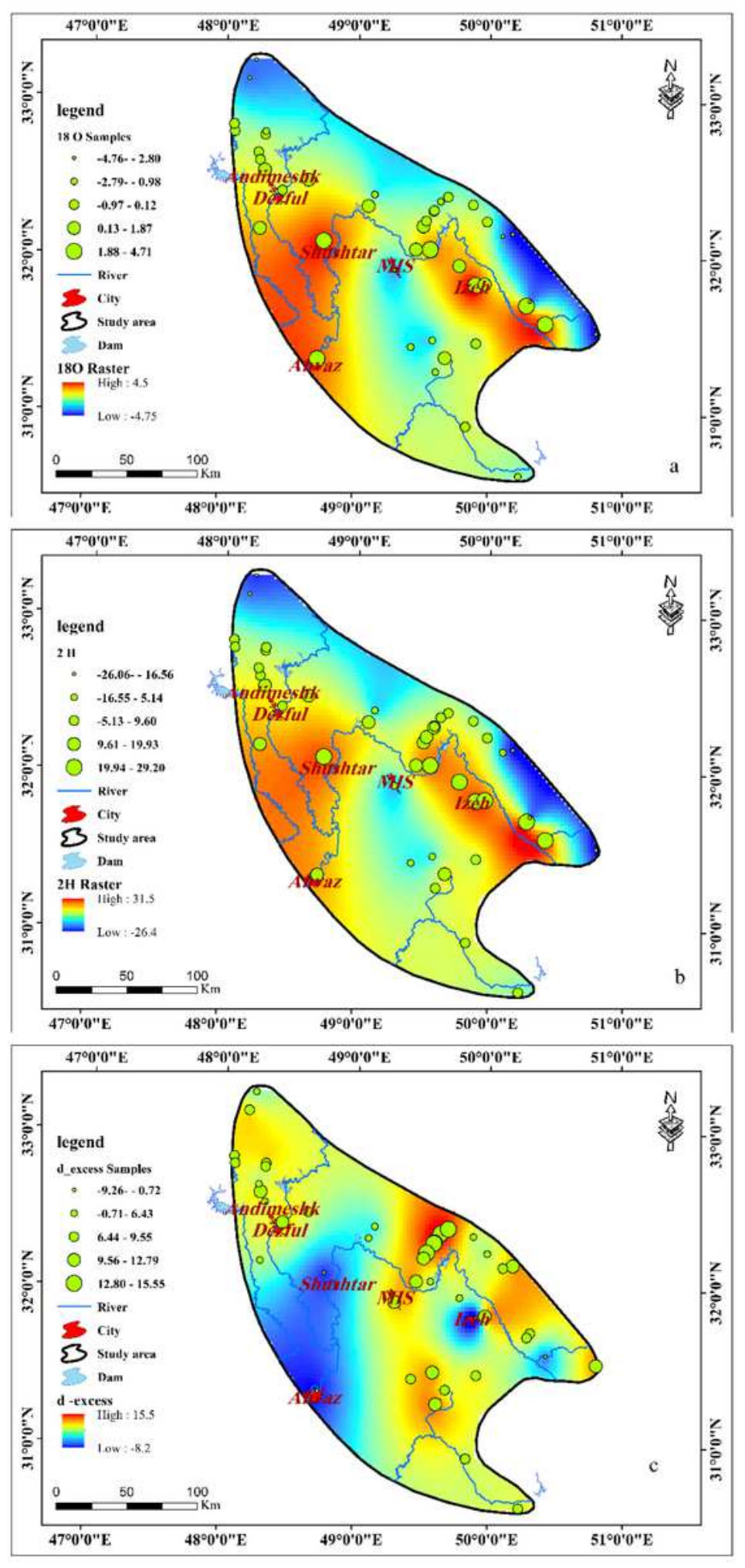

\section{Figure 3}

Distribution of (a) $\delta 180$, (b) $\delta 2 \mathrm{H}$ (c) d-excess in rainwater samples throughout the study area during the storm event in April 2019. Note: The designations employed and the presentation of the material on this map do not imply the expression of any opinion whatsoever on the part of Research Square concerning the legal status of any country, territory, city or area or of its authorities, or concerning the delimitation of its frontiers or boundaries. This map has been provided by the authors. 


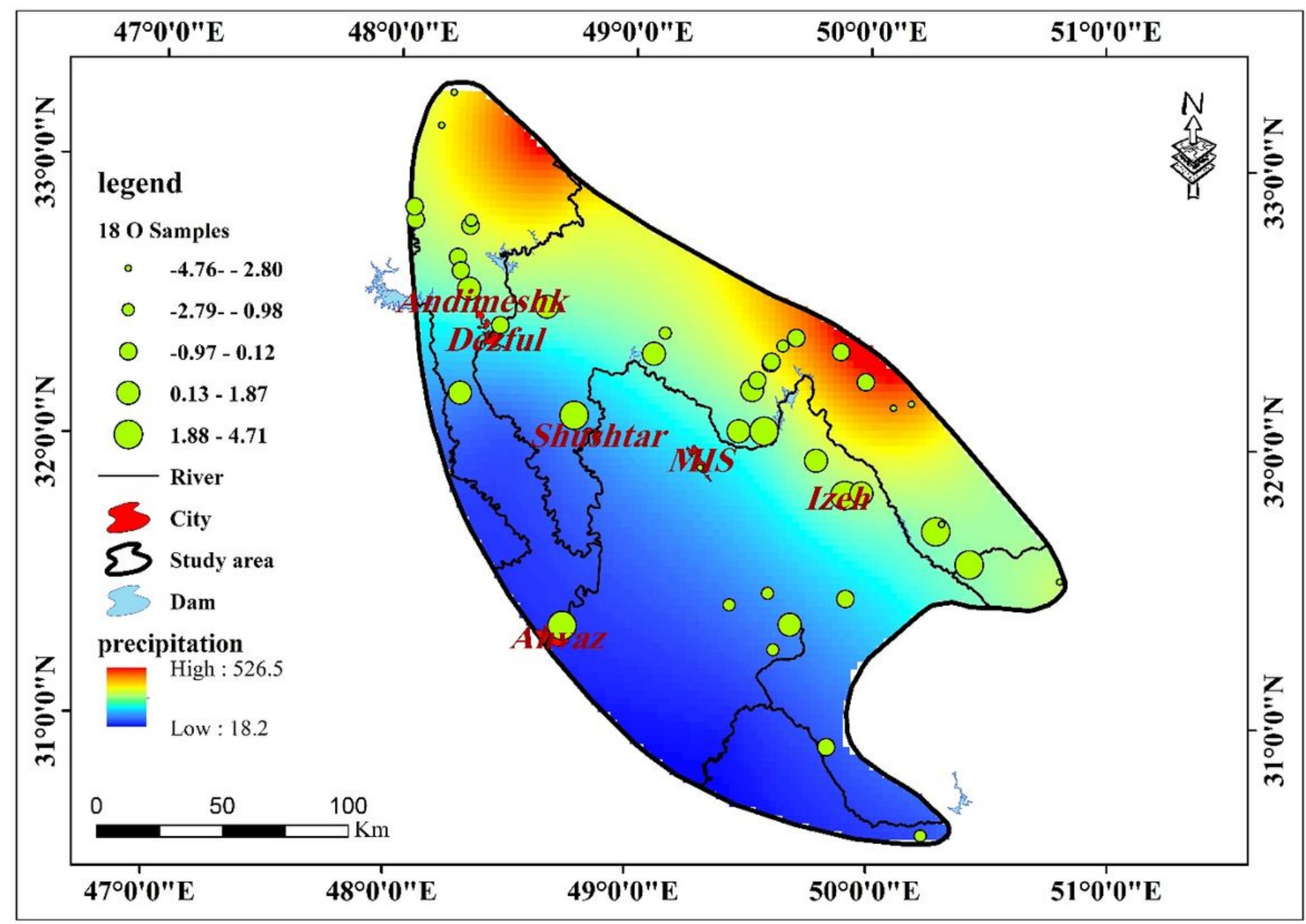

Figure 4

Map of iso-precipitation of the storm event (April 2019). Note: The designations employed and the presentation of the material on this map do not imply the expression of any opinion whatsoever on the part of Research Square concerning the legal status of any country, territory, city or area or of its authorities, or concerning the delimitation of its frontiers or boundaries. This map has been provided by the authors. 


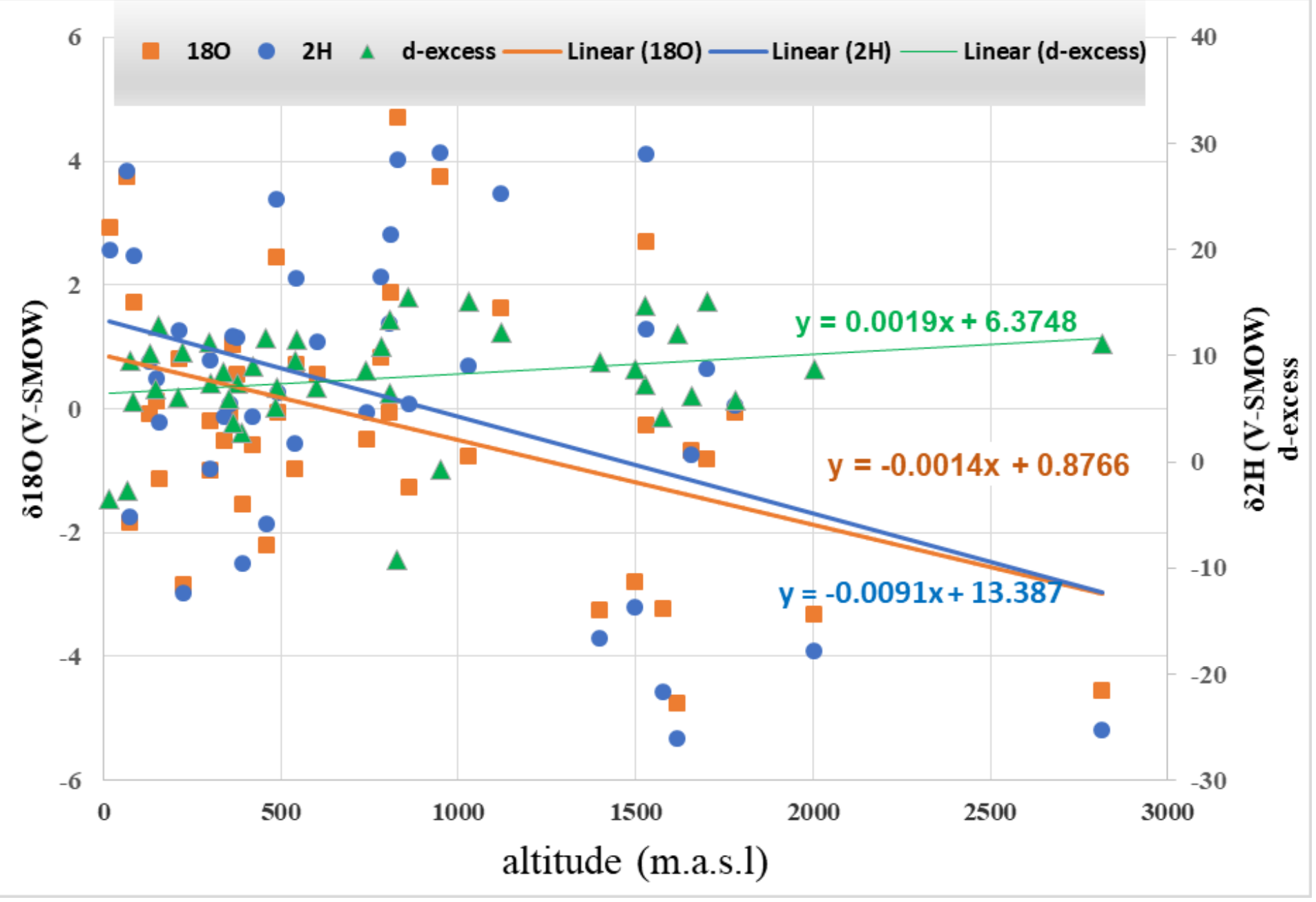

Figure 5

Correlation between altitude and isotopic values 


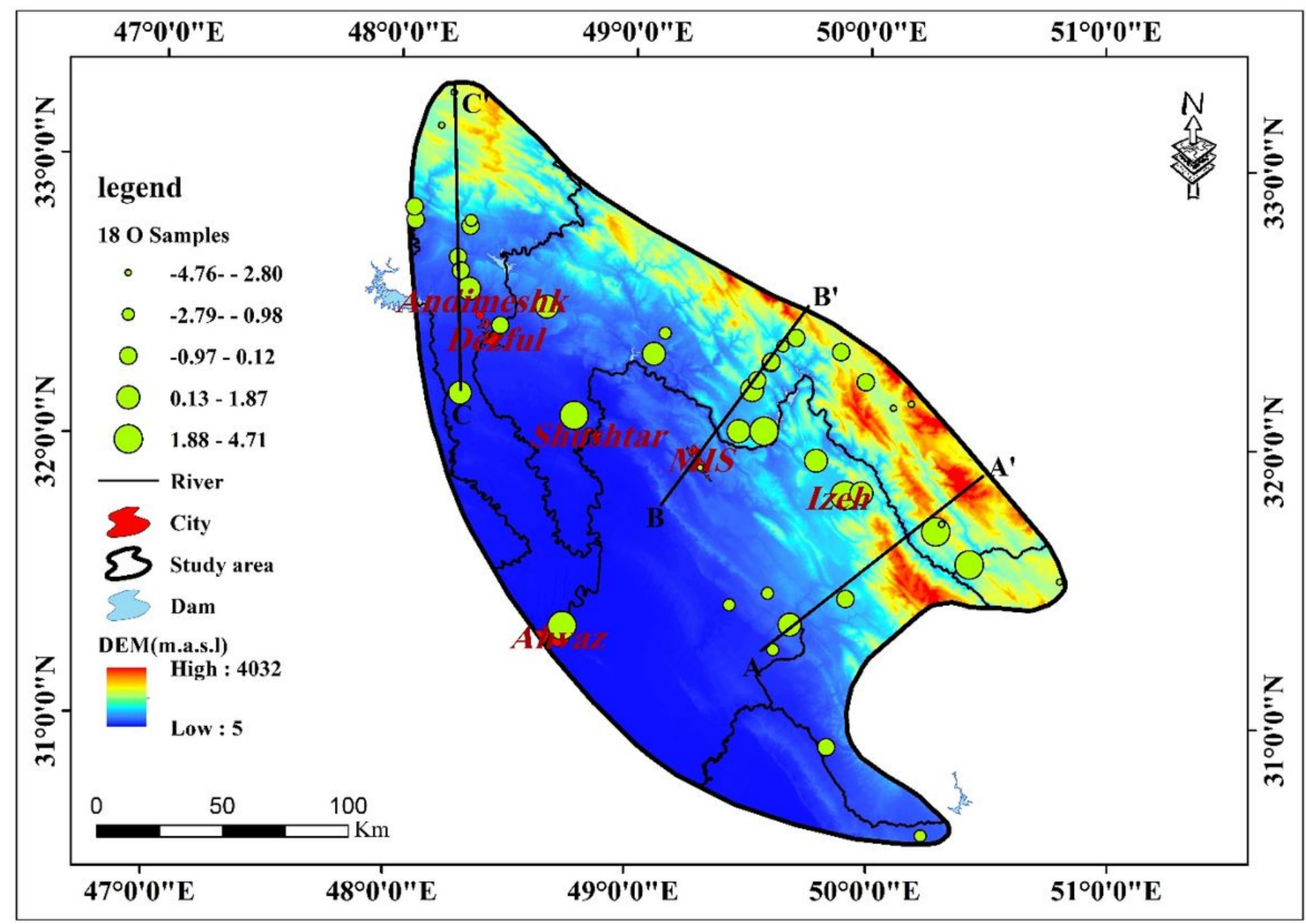

Figure 6

Digital Elevation Model (DEM) of study area and cross sections. Note: The designations employed and the presentation of the material on this map do not imply the expression of any opinion whatsoever on the part of Research Square concerning the legal status of any country, territory, city or area or of its authorities, or concerning the delimitation of its frontiers or boundaries. This map has been provided by the authors. 

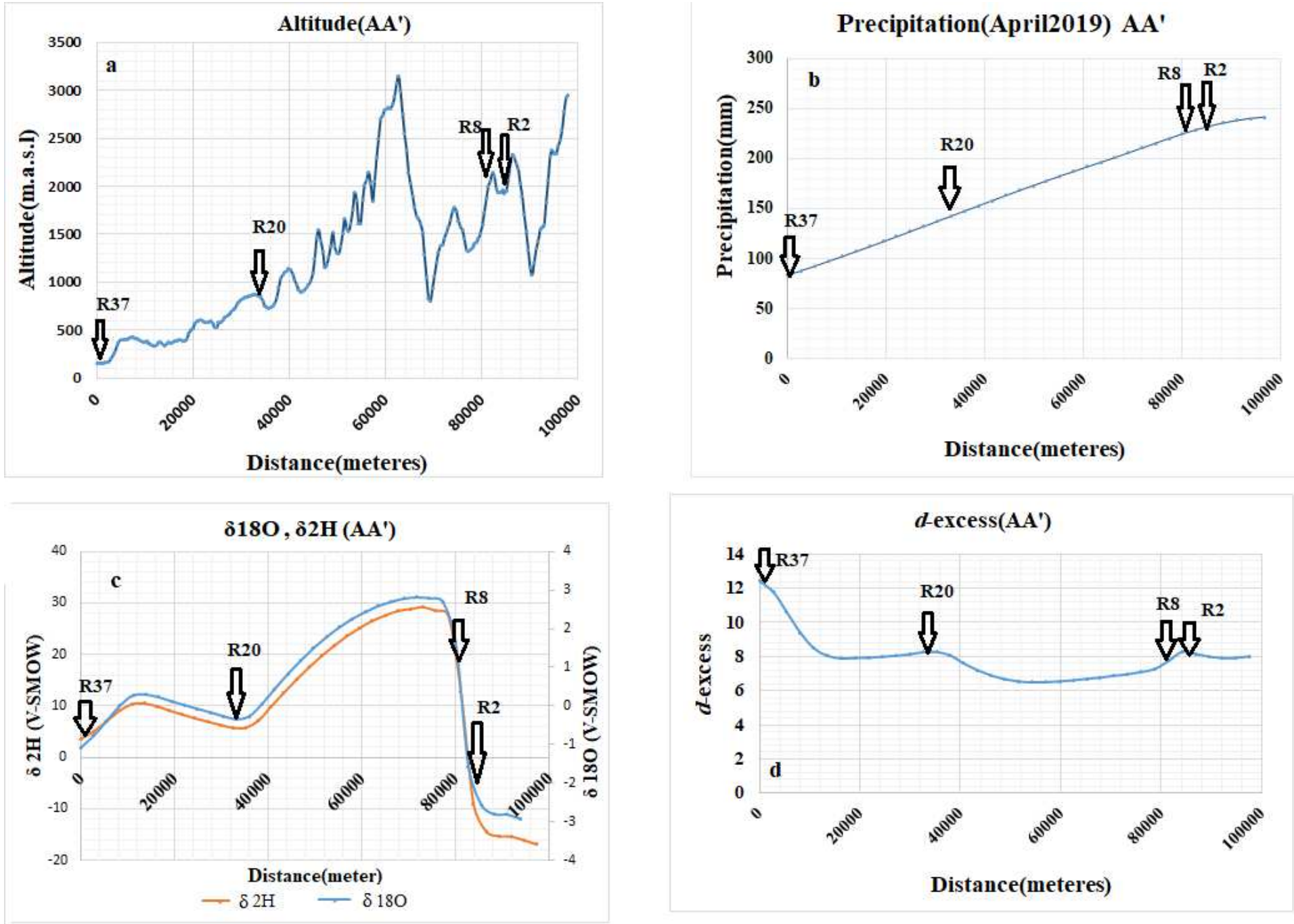

Figure 7

AA' cross-section in DEM of study area, a) altitude variation, b) precipitation, c) $\delta 180$ and $\delta 2 \mathrm{H}, \mathrm{d}$ ) dexcess 

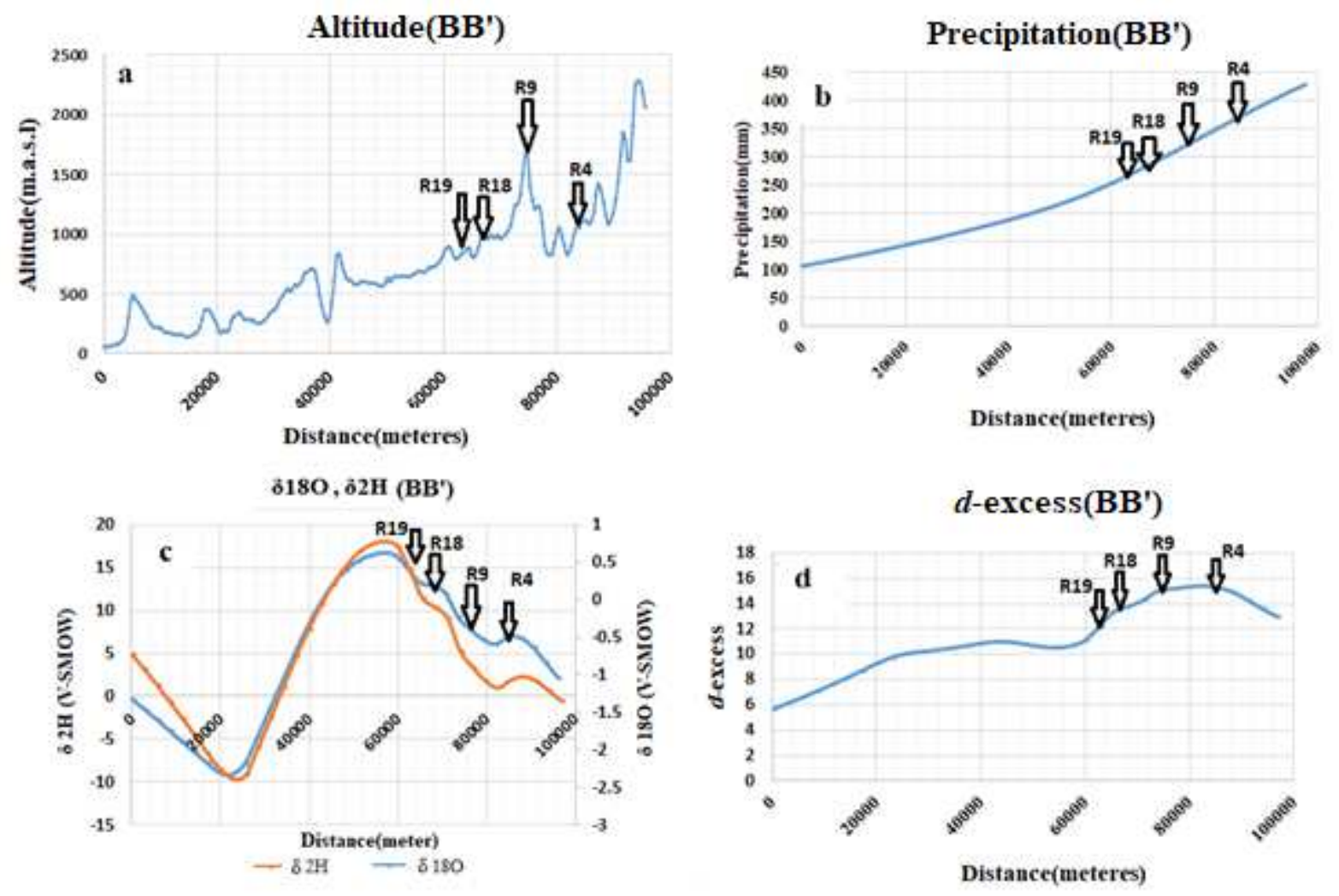

Figure 8

BB' cross-section in DEM of study area, a) altitude variation, b) precipitation, c) $\delta 180$ and $\delta 2 \mathrm{H}, \mathrm{d}$ ) $\mathrm{d}$ excess 

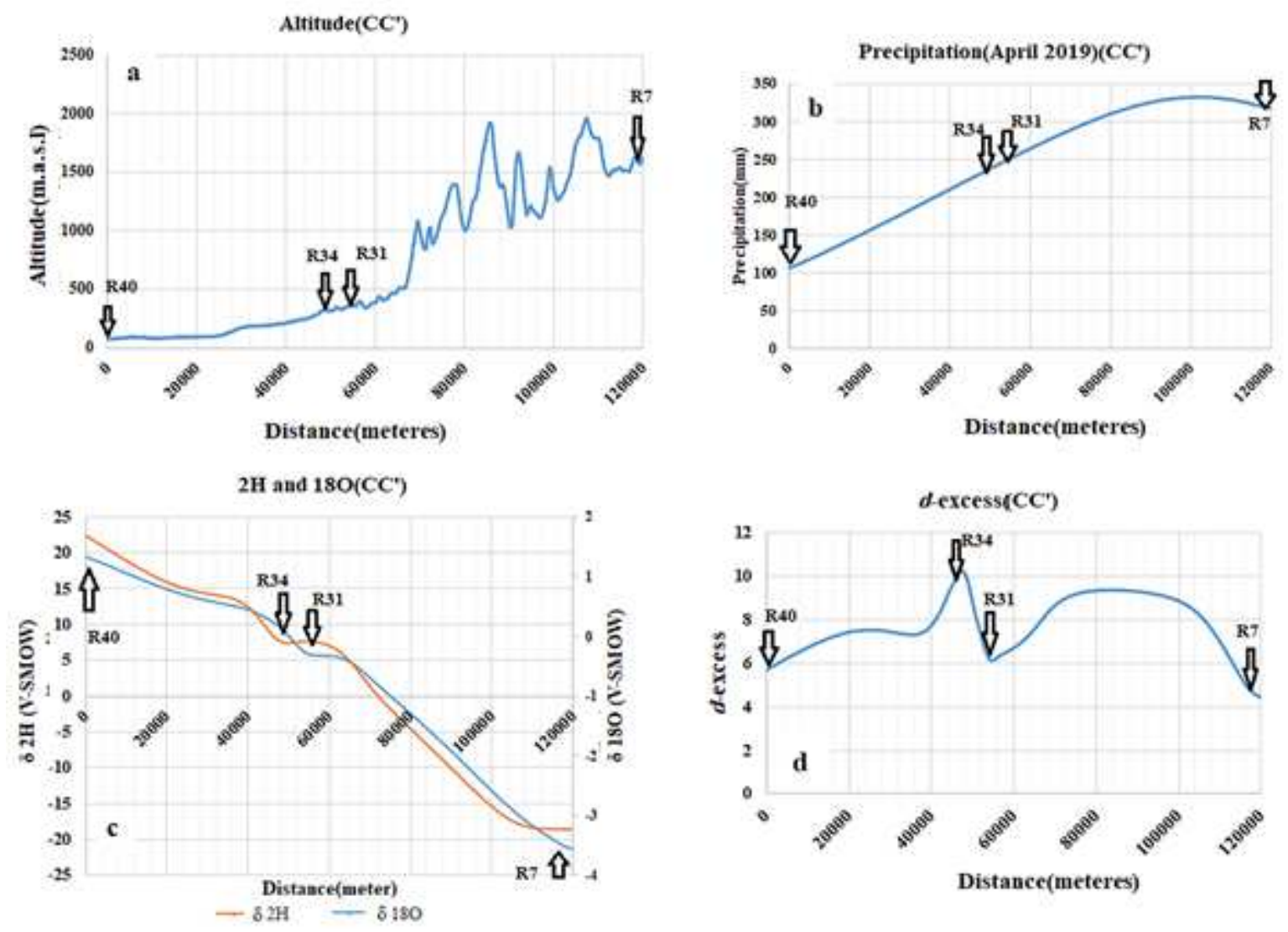

Figure 9

CC' cross-section in DEM of study area, a) altitude variation, b) precipitation, c) $\delta 180$ and $\delta 2 \mathrm{H}, \mathrm{d}$ ) $\mathrm{d}$ excess

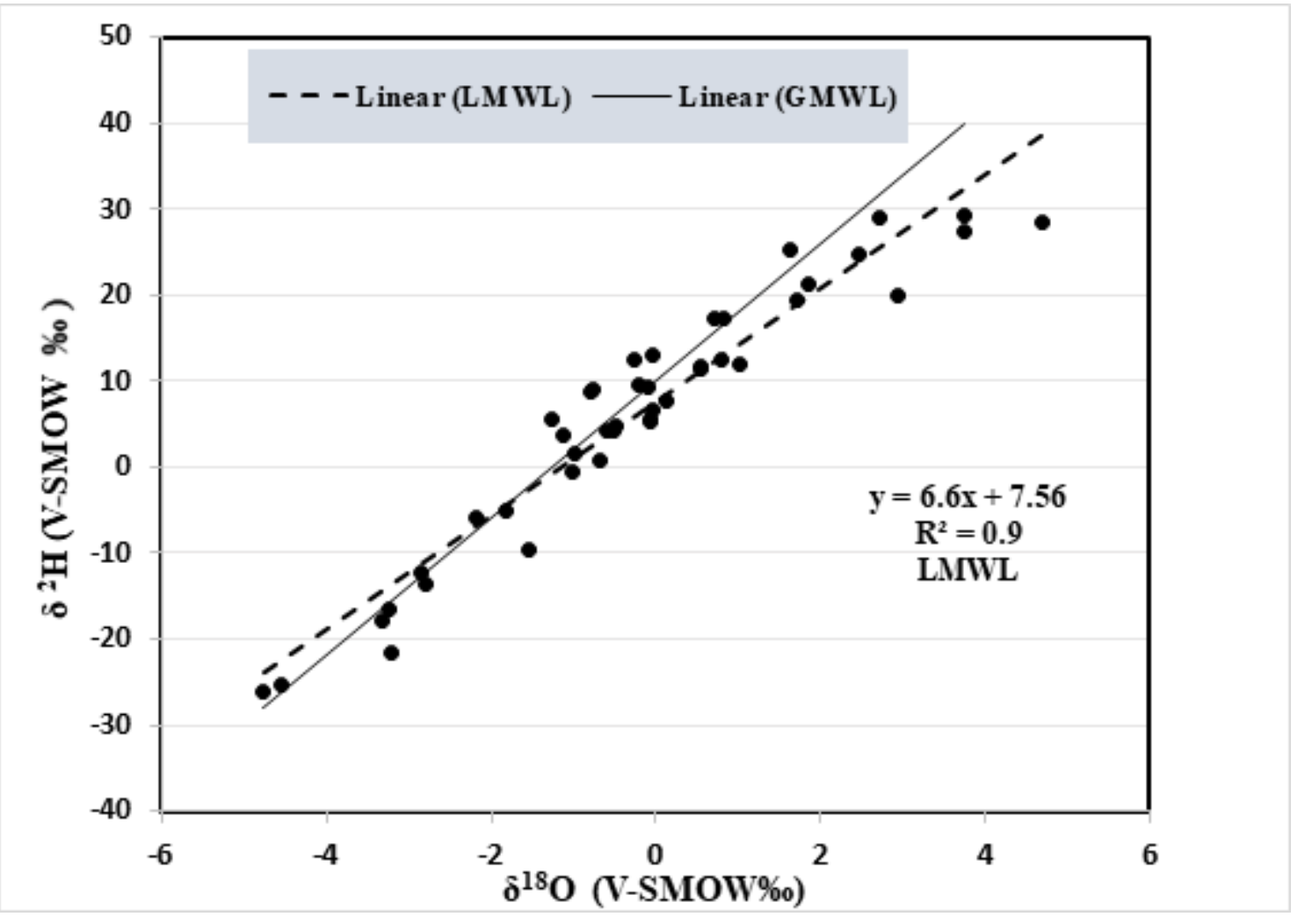


Figure 10

Plotted rain water samples on $\delta 2 \mathrm{H}$ vs. $\delta 180$ diagram LMWL and compared with GMWL

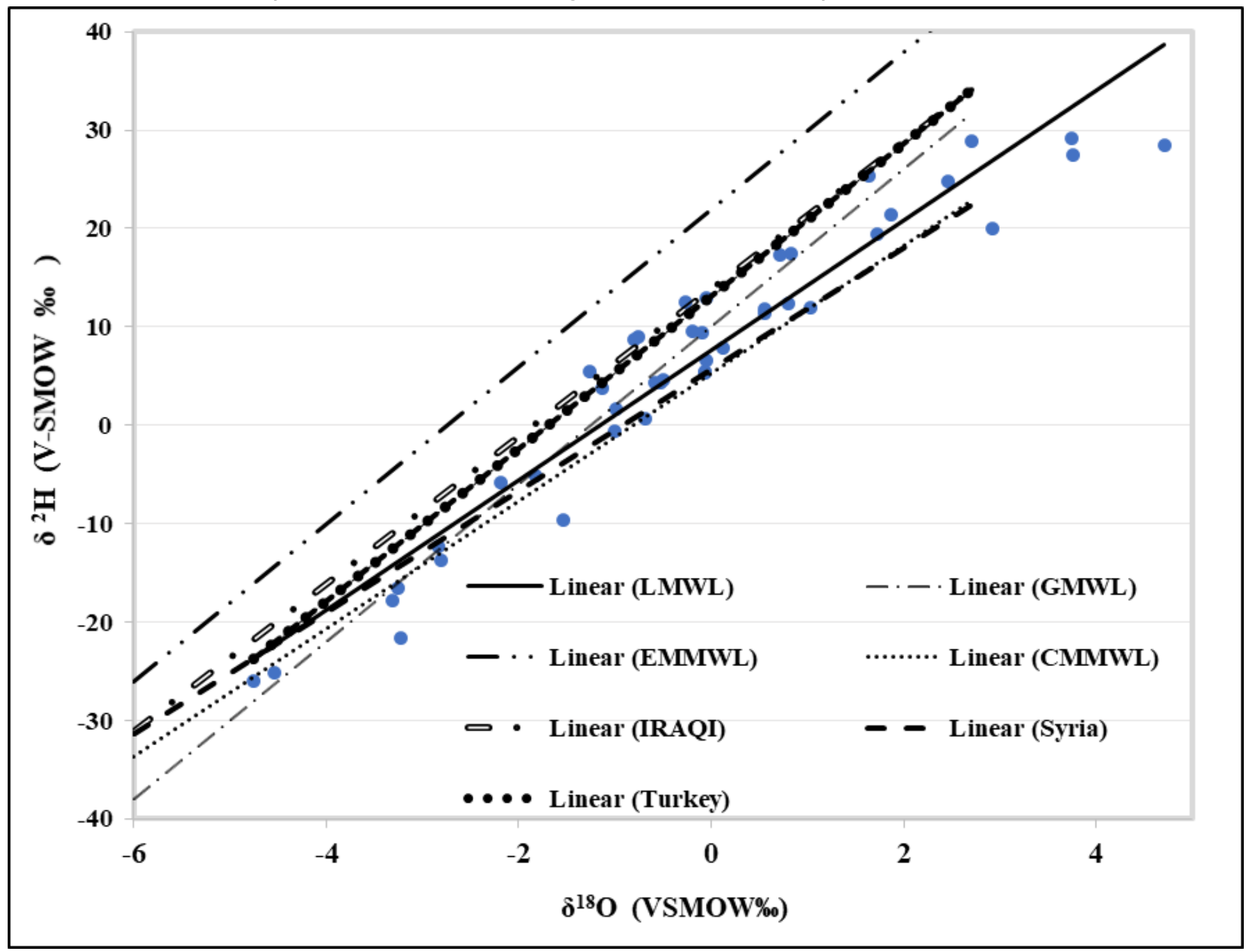

Figure 11

LMWL (April 2019), compared with GMWL, EMMWL, CMMWL and Adjacent Countries (Turkey, Syria and Iraq) 


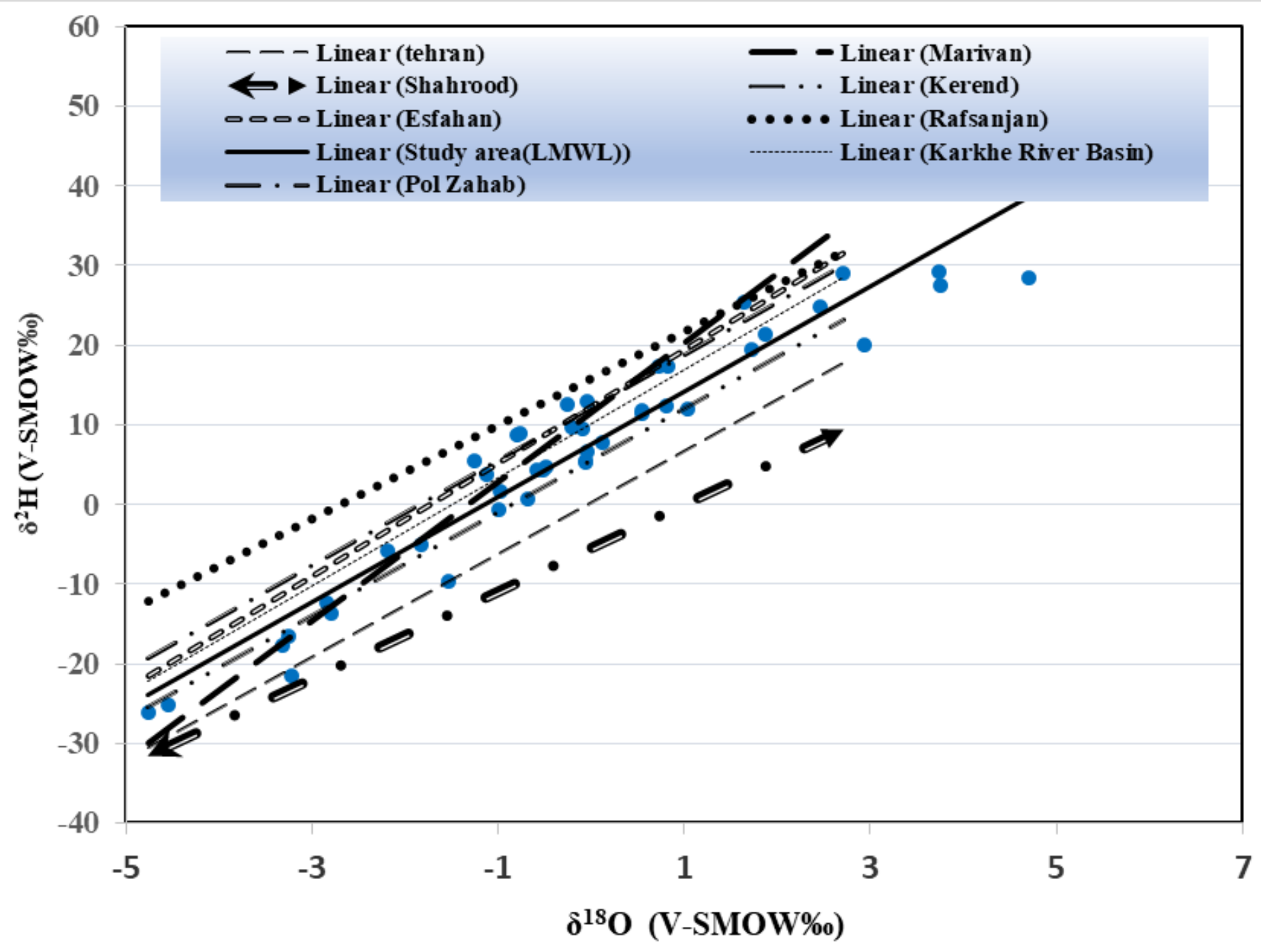

Figure 12

Local meteoric water line (LMWL) of some parts of Iran in present study 